Professor Tison's office, which is probably the only way in which the whole bulk of the transactions of the Commission can appear in reasonable time.

At the end of the Conference of the I.U.G.G. the question of the International Geophysical Year 1956-57 was discussed by an International Committee upon which Professor G. Manley acted as representative for Great Britain.*

The next Assembly of the I.U.G.G. will be held in Buenos Aires in 1957. It is to be hoped that it will not be unfortunate for the Commission on Snow and Ice that it is to be held in a country where hitherto there has not been much glaciological study and where distance may be a handicap for many European glaciologists. It may be, however, that the newly formed National Institute of the "Continental Ice" of Patagonia will have results to contribute by then.

In the course of the meetings the President read a message from Dr. P. L. Mercanton suggesting that a tour of the Swiss glaciers for members of the Commission should be arranged in conjunction with the next triennial Assembly. This may now prove less easy in view of its taking place in South America; but it could still be held if the date were early enough not to clash with the main meeting of the Commission. Alternatively it might take place in the previous year. Such a tour would undoubtedly be popular and is very desirable. It might be better for some more corporate body than the Commission, such as this Society, to make the arrangements.

In accordance with the principle decided in I95I at Brussels no subjects have been set for the papers to be read in 1957 . This proved eminently satisfactory at Rome and provided valuable papers in the many widely differing and rapidly developing aspects of glaciology.

For the next triennium Professor R. Haefeli (Zürich) takes the place of the retiring President. The Vice-Presidents are Professor R. Finsterwalder (Munich) and Professor A. Bauer (Strasbourg). The Commission is fortunate to be able to retain as Secretary, Mr. P. D. Baird, who is now resident in Scotland.

* A separate report appears on p. 482.

\title{
PAPERS READ BEFORE THE INTERNATIONAL COMMISSION ON SNOW AND ICE, I 954
}

\section{Glacier Temperature, Regime and Fluctuation}

The use of stakes in measuring the accumulation of snow on glaciers

Some factors affecting the temperature distribution in large ice sheets Fluctuations of the Nisqually Glacier, Mt. Rainier, Washington, during the last two centuries

Glaciothermal investigations on the Upper Taku Glacier, Alaska

Der Gletscherrückgang in den Ostalpen

Aires englaciées et altitudes des fronts des glaciers des alpes suisses et leurs variations d'après l'atlas Siegfried (1877) et la carte nationale (1932)

Sur le bilan hydrologique des bassins glaciaires avec application au Grand Glacier d'Aletsch

Glacier fluctuations in the Canadian Rockies

Studies of the variations in size of Swedish glaciers in recent centuries

Rapport sur les variations de longueur des glaciers d'Europe durant la périod I $950-1953$

Considérations sur les variations frontales des glaciers italiens au cours des quarante dernières années

Messungen der ablation und der Wärmeumsatz auf Alpengletschern

Summary of North American glacier fluctuations
C. W. M. Swithinbank $\dagger$

G. de Q. Robin

A. E. Harrison *

Maynard M. Miller

R. Finsterwalder

P. L. Mercanton $\uparrow$

P. Kasser

Calvin J. Heusser *

Erik Bergström $†$

P. L. Mercanton $t$

M. Vanni

H. Hoinkes

W. O. Field *
Great Britain

Great Britain

United States

United States

Germany

Switzerland

Switzerland

United States

Sweden

Switzerland

Italy

Austria

United States

\section{Glaciers and Ice Cover (Various)}

Ice thickness measurements in Queen Maud Land, Antarctica

Glaciological studies in the Penny Highland, Baffin Island, 1953

Observations on the Nisqually Glacier and other glaciers in the northwestern United States

Pressure release and glacial erosion

On the occurrence of ice domes and permanently snow-covered summits
G. de Q. Robin †

W. H. Ward

A. Johnson*

W. V. Lewis

Gordon Manley
Great Britain

Great Britain

United States

Great Britain

Great Britain 
Observations dans une calotte glaciaire froide

Bericht über die glaziologischen Arbeiten am Unteraargletscher Report on glaciological investigations during the Norwegian-British-Swedish Antarctic Expedition, 1949-1952

Les résultats glaciologiques des Expéditions Polaires Françaises

Etudes séismiques sur l'Inlandsis du Groenland

Le Glacier de la Marmolada

Les glaciers du Val d'Aoste

Le Glacier du Calderone du Gran Sasso d'Italia
R. Haefeli and F. Brentani W. Jost +

V. Schytt $\uparrow$

A. Bauer

J. Holtzscherer $\ddagger$

D. Tonini

M. Vanni, G. Aliverti

and $\mathrm{F}$. de Gemini

D. Tonini
Switzerland

Switzerland

Sweden

France

France

Italy

Italy

Italy

\section{Snow and ICE Physics}

Force exerted on snow during its break-down

A study on the optical and acoustical properties of the snow cover The dielectric property of snow

Electron microscope study of snow crystal nuclei

Sorne studies on the mechanical properties of snow

Acceleration of metamorphosis of snow by temperature gradient

On heat conductivity of snow

Flow and recrystallisation of ice

Some observations on the banding of glacier ice

Cinematographic study of ice crystal formation in water

$\begin{array}{ll}\text { Z. Yosida and } & \text { Japan } \\ \text { S. Kinosita * } & \text { Japan } \\ \text { H. Oura * } & \text { Japan } \\ \text { D. Kuroiwa * } & \text { Japan } \\ \text { M. Kumai * } & \text { Japan } \\ \text { Z. Yosida and } & \text { T. Huzioka * } \\ \text { Z. Yosida and } & \text { Japan } \\ \text { K. Kojima * } & \\ \text { M. de Quervain † } & \text { Switzerland } \\ \text { S. Steinemann † } & \text { Switzerland } \\ \text { N. Untersteiner } & \text { Austria } \\ \text { M. Kumai and } & \text { Japan }\end{array}$

\section{SNOw (VARIOUs)}

Measurement of water content of snow

Classification of snow deposit

Snow control of the Shelterbelt

La structure des pénitents de neige

Die Bestimmung der Schneehöhenverteilung auf photogrammetrischem Wege

Lysimeter studies of runoff from a deep snow pack

Carte des neiges du Bassin du Pô
M. Kuroda and

I. Hurukawa

M. Kuroda and

C. Gondahira

M. Shiotani and

H. Arai *

L. Lliboutry

Th. Zingg †

D. M. Rockwood, P. B. Boyer and

C. E. Hildebrand $\uparrow$

F. Abadessa
Japan

Japan

Japan

Chile

Switzerland

United States

Italy

\section{River AND Sea ICE}

A summary review of ten years' work in the domain of sea ice on the Okhotsk Sea coast of Hokkaidó

Historical review of studies on sea ice in Japan

Some remarks on the method of sampling of sea ice

Glaciological reconnaissance in Northern Ellesmere Island

Entstehung und Bekämpfung von $\mathrm{E}$ is in stehenden und fliessenden Gewässern und insbesondere an Stauanlagen

Experimental studies on freezing of water

Formation and movement of floating ice in Dutch rivers, with special reference to the tidal region

The influence of an ice-cover on the discharge conditions of a river

An investigation concerning the balance of heat in a river during violent frost

Etude sur la croissance de la glace dans le fleuve Soungari (Mandchouri Chinoise)

Probleme der Meereisforschung

\section{T. Fukutoni * \\ Kou Kusunoki * \\ Kou Kusunoki and \\ T. Tabata* \\ K. Th. Strauch $t$ \\ K. Arakawa * \\ P. Santema and \\ K. F. Valken \\ P. J. Wemelsfelder \\ P. J. Wemelsfelder \\ M. Murakami* \\ F. Nusser}

G. Hattersley-Smith + Canada

Japan

Japan

Japan

Germany

Japan

Netherlands

Netherlands

Netherlands

Japan

Germany

\section{VARIOUS}

Effect of antecedent base flow in forecasting runoff of the Columbia River from snow survey data

A review of soil freezing as affected by snow cover, plant cover and soil conditions in northwestern United States

On the infuence of the water equivalent of the snow cover on the water supply in Finland

C. C. McDonald and M. W. Nelson $t$ W. E. Bullard $t$

A. Sirèn
United States

United States

Finland

* Read by title.

+ Read in absentia.

\pm Read before a joint meeting of the Associations of Hydrology and Seismology. 